\title{
A trait database for Phytoplankton of temperate lakes
}

\author{
Frédéric Rimet ${ }^{*}$ and Jean-Claude Druart \\ UMR Carrtel, INRA, Université de Savoie, 75 av. de Corzent - BP 511, 74203 Thonon-les-Bains cedex, France
}

Received: 18 December 2017; Accepted: 2 March 2018

\begin{abstract}
Phytoplankton is a choice ecological indicator of lake ecological quality. Microalgae composing this biological compartment display a large diversity of morphological, physiological and ecological features, which are useful for understanding the interactions they have with other biotic and abiotic elements. Such kind of information together with classical Utermöhl phytoplankton analyses are useful for lake management and basic science. We present here a reference database of morphological (cell and colony sizes, biovolumes, mobility apparatus, colony formation), functional (functional groups of Reynolds, Padisak and Kruk, zooplankton edibility groups), physiological (trophic capacities) and ecological traits (Brettum index values) of more than 1200 taxa often observed in temperate lakes. This database, maintained since the 70's until nowadays by the authors of this paper is now realized open access in Zenodo (https://zenodo.org; DOI: 10.5281/zenodo.1164834) and also as supplementary material on the journal website. The paper presents an overview of its content.
\end{abstract}

Keywords: Biovolume / functional groups / microalgae / morphological traits / taxonomy

\section{Introduction}

Phytoplankton is the most often used ecological indicator of lakes ecological quality because its biomass and species composition are directly affected by anthropogenic activities. In many cases human activities is at the origin of eutrophication phenomena and they have a well know impact of phytoplankton (Pinay et al., 2017). More than 170 publications were published on the impact of eutrophication of phytoplankton in the Web Of Science until 2017, which is a proof of the interest about this topic. Compared to benthic microalgae, there are ten times more published studies about phytoplankton (Cantonati and Lowe, 2014). Indeed, phytoplankton gives a good picture of the overall ecological quality of a lake (e.g. Thackeray et al., 2013) and for such reason it has a long legacy especially in the routine monitoring of large lakes surrounded by dense populations. It is also a required ecological indicator for lakes and larges rivers of US federal (Copeland, 2016) and European transnational (European Commission, 2000) legislations.

Large peri-alpine lakes in Western Europe are an excellent illustration of this situation. This is in particular the case of the largest deep lake in Western Europe, Lake Geneva situated on the border between France and Switzerland. More than 950000 people now inhabit its catchment area and it suffered strong eutrophication in the 60 's- -70 's. After the first efforts in the 70 's to limit pollution and its impact of the lake, the trophic

\footnotetext{
*Corresponding author: frederic.rimet@inra.fr
}

status of Lake Geneva gradually changed until nowadays, since it is now in on a meso-oligotrophic status (e.g. Anneville et al., 2017). To measure the benefit of restauration actions of ecological quality in this lake, phytoplankton has been monitored every two weeks (or every month during winter season) with the same sampling methodology since 1974 (Rimet et al., 2009): an integrated sample between 0 and 18-m depth is carried out above the deepest point. Then samples were analyzed under microscope (counting, determinations) following a given methodology (Utermöhl, 1958), now standardized at European level (Afnor, 2006).

Since the 60's-70's, scientific reports were delivered to lake Geneva managers. Phytoplankton is an important item of these reports and even if the taxonomic inventories were produced using the same methodology - and this enable a good comparability throughout the years- they were presented using different traits from a decade to another; which is due to the evolution of knowledge about microalgae ecology. For instance in the 70 's, reports were simply presenting monthly phytoplankton biomasses and species richness (e.g. Lang, 1975). Then in the 80's, the authors (e.g. Revaclier et al., 1988) of these reports started to use the relative biomasses of algal classes and of size classes (e.g. nanophytoplancton/microphytoplancton) since these traits are good descriptors of trophic level (e.g. Thunmark, 1945; Nygaard, 1949) and of edibility for zooplankton (Makarewicz et al., 1998). In the 90's, authors of the reports (e.g. Pelletier et al., 1997) used ecological information about nutrient preferences of algal classes and species from literature and information about colony shape (e.g. filamentous/coenobial/mucilaginous) which 
are also good indicators of microalgae nuisances. For instance, filamentous algae, like Mougeotia gracillima in lake Geneva, when blooming, clog professional fishermen nets and this reduce their fishing catch (Tapolczai et al., 2016), or can form toxic blooms like the cyanobacteria Planktothrix rubescens in lake Bourget (Kerimoglu et al., 2017). In the 2000s, rather precise notions of ecological niches of species appeared in the reports (e.g. Druart et al., 2004) coming from the scientific literature (e.g. Anneville et al., 2002) for instance the ecological niche of Stephanodiscus species (alpinus, neoastraea) is described as they occur in meso-eutrophic lakes during winter when the water column is mixed. After 2007, use of functional groups described in Reynolds et al. (2002) explaining the seasonal and long-term evolution of phytoplankton communities (e.g. Rimet and Druart, 2009) appeared because they summarize with robustness phytoplankton ecology and are good indicators of lake ecological quality and functioning. Furthermore, biotic indices like the Brettum index (Brettum, 1989; Dokulil et al., 2005) and information about mixotrophic capacities of species were used to assess the trophic evolution of the lake.

The authors of this paper have regularly updated a database of traits during more than 50 years with species they observed in the large peri-alpine lakes in France (Geneva, Annecy, Bourget, Aiguebelette) but also in high altitude lakes in the French Alps (Feret et al., 2017) and various other lakes (e.g. Lac du Der, Lac de Nantua, Lac de Miribel ...). This database encompass more than 1200 taxa and more than 50 traits of various types (types according to the definitions of Violle et al., 2007): functional traits, performance traits, Ecological traits performances.

The objective of this paper is to describe this database, hosted on a Windows Excel $\bigodot$ spreadsheet, released openaccess with this publication in Zenodo (https://zenodo.org; DOI:10.5281/zenodo.1164834) and also as supplementary material on the journal website. It is hereafter called Appendix 1.

\section{Methodology}

\subsection{Cell and colony sizes and biovolumes}

Appendix 1 gives for each taxon its cell dimensions, length, width, thickness (also called in some cases "hidden" dimension) and its best fitting geometric shape. Cell (and colony) dimensions origin is given in the column "Notes on biovolumes". Nine different geometrical shapes are used (ellipse, cuboid, tube, double cone, triaxial ellipsoid, sphere, cone, rhomboid prism, prism) which is much smaller than the 43 different shapes given in the European standard for the determination of phytoplankton biovolumes (European Standardization Committee, 2014).

If the geometrical shape selected corresponds exactly to the shape of the cell, a multiplicative factor of " 1 " is applied to the geometrical formula to get the final taxon biovolume. This is the case of a Chlorella vulgaris cells in Figure 1a, which shape are a perfect sphere and therefore the biovolume of one cell is corresponding to the formula of a sphere with a multiplicative factor of " 1 ".

But in some cases, the best fitting geometrical shape do not correspond exactly to the cell shape and therefore the biovolume is over estimated. In such case, this multiplicative factor is below 1 and is applied in order to reduce the estimation of the taxon biovolume. This factor is based on a subjective estimation (after a careful observation under microscope) the space the cell occupies in the geometrical shape. For instance, we consider that the best fitting shape of Cymbella C. Agardh species is a box. But shape of Cymbella is not exactly corresponding to a box. Therefore a multiplicative factor of 0.7 is applied to get a correct estimation of the biovolume of Cymbella species since it is smaller than a box. Figure $1 \mathrm{~b}$ illustrates this situation.

The surface area of the cell is calculated on the basis of the geometrical shapes formula. Similarly, if the geometrical shape do not correspond exactly to the cell shape, the surface area obtained with the geometrical formula will be divided by a subjectively estimated factor (called "dividing factor" in Appendix 1).

In the case of a colonial taxon, the number of cells in a colony is given. For instance, the mucilaginous Cyanobacteria in Figure 1c has 13 cells and the Scenedesmus Meyen has 4 cells (Fig. 1d, e). In Appendix 1, the colony biovolume is estimated using two ways:

- the first way is with the cumulated biovolume of the cells in a colony. For this, the biovolume of one cell is multiplied by the number of cells in a colony. For instance, the biovolume of one cell will be multiplied by 13 since there are 13 cells in the case of the mucilaginous cyanobacteria of Figure 1b. Figure 1d illustrates this for a Scenedesmus colony (or coenobe) composed by 4 cells;

- the second way is based on the colony sizes and shapes. For this, shapes and colony sizes (length, width, thickness) taking into account the mucilage, are given together with a multiplicative factor. This factor estimates subjectively the proportion of biovolume that cells occupy in the colony shape. For instance in Figure 1c, the biovolume of the colony will by calculated on the basis of a triaxial ellipsoid which size encompass the mucilage and will be multiplied by a factor of 0.1 , since cells occupy approximately $10 \%$ and the mucilage approximately $90 \%$ of the colony. Figure 1e illustrates this for a Scenedesmus coenobe which fit $80 \%$ a box volume.

These two ways to calculate a biovolume have pro and cons. In the case of small colonies composed by a small number of cells, which are easily countable, the first way is preferred. On the other hand in the case of large colonies (e.g. colony of Microcystis aeruginosa (Kützing) Kützing of $100 \mu \mathrm{m})$, the number of cell is hardly countable, and the second way is preferred.

Finally, in Appendix 1, the surface area of the colony is given based on the colony sizes, shapes and dividing factor dedicated to colony.

In case of filamentous colonies, the biovolumes and surface areas of the colonies are given for an arbitrary length of $100 \mu \mathrm{m}$ (usually the length of the filaments are longer). This is the case for filamentous Cyanobacteria, Chlorophyta, Xantophyta. But, there are cases for which the biovolumes and surface areas of the colonies of filamentous taxa are not given for filaments of $100 \mu \mathrm{m}$. This is the case of Cyanobacteria taxa, which show short filaments (e.g. Romeria M. Koczwara). In 


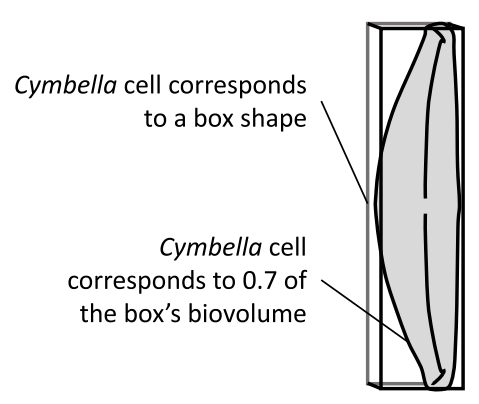

(b)



(c)

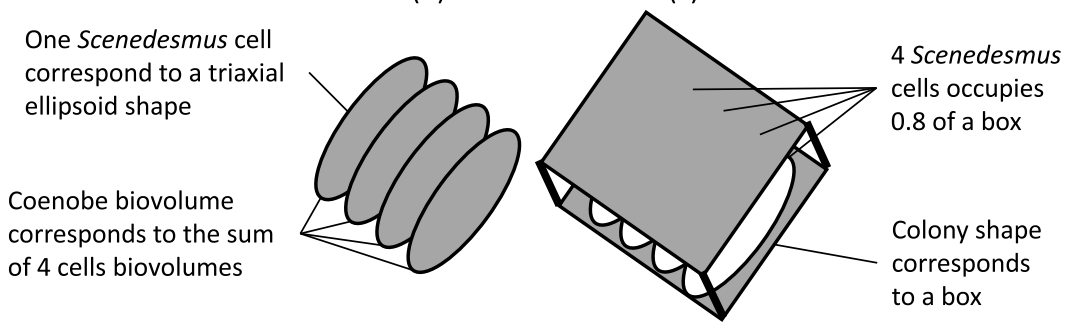

(d)

(e)

Fig. 1. Illustration of the biovolume calculations. (o) Case of a cell of Chlorella vulgaris which cell shape attribution in Appendix 1 is a sphere (a) Case of a cell of Cymbella which cell shape attribution in Appendix 1 is a box; a multiplicative factor of 0.7 is applied to the volume of the box to get the biovolume of the Cymbella cell. (b) Case of a mucilaginous Cyanobacteria colony. The first way to calculate the biovolume is to measure a cell dimension and calculate the biovolume of one cell based on a triaxial ellipsoidformula; the biovolume of one cell is multiplied by 13 (the number of cells in the colony) to get the colony biovolume. The second way is to measure the colony dimensions (taking into account the mucilage) and to calculate the biovolume of the colony based on a triaxial ellipsoid. Finally this volume is multiplied by a factor of 0.1 (the cell volume is estimated to be $10 \%$ of the mucilaginous colony) to get the colony biovolume. (c) and (d) give the case of a Scenedesmus coenobe biovolume calculation. The first way (c) to calculate the biovolume, is to measure the cell dimensions and to calculate its biovolume based on a triaxial ellipsoid ; then the cell biovolume is multiplied by 4 ( 4 cells in the coenobe) to get the coenobe biovolume. The second way (d) to calculate the biovolume, is to measure the coenobe dimensions; in this case the coenobe shape is associated to a box. The box volume is calculated. Since the coenobe volume is smaller than the box volume, the box volume is multiplied by a factor of 0.8 to get the coenobe volume (the coenobe volume is estimated to be $80 \%$ of the box).

this case, the average length of the colony (usually below $100 \mu \mathrm{m}$ ) of the taxon is used to calculate the biovolume and surface area of the colony. Similarly, the lengths of filaments of Planctonema lauterbornii Schmidle (Chlorophyta) are on average $50 \mu \mathrm{m}$, therefore, biovolume and surface area of its colony given in Appendix 1 is calculated with a length of $50 \mu \mathrm{m}$. In the case of filamentous diatoms (e.g. Achnanthidium catenatum (Bily \& Marvan) Lange-Bertalot, Aulacoseira Thwaites, Fragilaria Lyngbye, Melosira C. Agardh ...), the biovolume of the colony is not given because the lengths of the filaments can be very different from a sample to another. This is also the case of several Zygophyceae species (e.g. Mougeotia gracillima (Hassall) Wittrock, Spondylosium Brébisson) which can be filamentous but which are also often unicellular when the environment is turbulent. Therefore the colonial biovolume and surface area of these Zygophyceae taxa are not given.

The maximal length of the taxon is given in Appendix 1: if the taxon is unicellular, it is the maximal length of the cell, if it is colonial it is the maximal length of the colony. Finally, we give in Appendix 1 the "Reference biovolume" of each taxon, which is the chosen biovolume (among the two possible biovolumes calculations for colonial taxa) for routine countings, did by the authors in the framework of the lake monitoring.

\subsection{Morphological, metabolic and trophic traits}

Several morphological traits are given in Appendix 1. The first one is the cell mobility apparatus is described if it is a flagella or a raphe system (for diatoms). These to kind of mobility are far different: flagella enable cells to swim in water, raphe system enable diatoms to glide on a substrate. The second morphological trait given in Appendix 1 specify if the algae is colonial, and if it is, it precise if this is a filamentous colonial shape.

Metabolic types are given for each taxon. Three different categories are given to algal classes and their subsequent taxa: autotrophic, mixotrophic and heterotrophic. Several taxa in Appendix 1 are heterotrophic, this can sound surprising since phytoplankton should be composed exclusively by 
photosynthetic taxa. This is not the case because a few taxa were formerly considered as photosynthetic, whereas recent studies show they were not. This is the case for instance of the genus Salpingoeca H.J. Clark considered to be part of Chysophyceae (a photosynthetic algal class) in Bourrelly (1981), whereas it is part of Choanoflagellates (an autotrophic protist class). These classes were attributed after consideration of various literature references (e.g. Jones, 2000; Stickney et al., 2000; Salmaso and Padisak, 2007; Tittel et al., 2009). These taxa are traditionally counted in phytoplankton whereas they are not photosynthetic.

The Brettum index is a biotic index, calculated on phytoplankton communities, adapted to large and deep alpine lakes to assess phosphorus concentration (modified after Brettum, 1989; Dokulil et al., 2005). To calculate this index, two different traits are used. The first is a species biomass in the sample (performance trait) and the second is the presence probability of the species along the phosphorus gradient (ecological performance). Appendix 1 gives the trophic traits of the species integrated in this index: they are composed by 6 classes of phosphorus concentrations in which are given the presence probability of the species. The presence probabilities are ranking from 0 (species absent) to 10 (very high probability that the species is present). This index is routinely used to assess phosphorus level in large peri-alpine lakes in France (e.g. Jacquet et al., 2017; Rimet et al., 2016).

\subsection{Functional and morphological classifications}

In Appendix 1, two functional classifications are given, the one of Reynolds et al. (2002) thereafter modified by Padisak et al. (2009). In the sense of these authors, a functional group gathers species that live in the same kind of habitat. These groups can be made of polyphyletic species but which developed sometimes different kind of adaptations, which enable taxa to be present in the same kind of habitat (Tapolczai et al., 2016). Nevertheless, species belonging to the same group are not necessarily found in association in the same place at the same time, for instance simply because they may compete and exclude each other.

The classification of Reynolds et al. (2002) is made of 31 groups, where the habitat is mostly described in terms of water stability, nutrient level, depth, light intensity, water-body size. For instance, the functional group A gathers species living in lakes characterized by oligotrophic transparent waters, often mixed and with a neutral $\mathrm{pH}$. Typical representatives given in Reynolds et al. (2002) are listed in Appendix 1.

The classification of Padisak et al. (2009) is more extensive and encompass much more taxa. It is made of 40 groups (called codons). For each group, Padisak et al. (2009) also describe the habitat similarly to Reynolds et al. (2002), but add some particular habitats, like frequently stirred up shallow lakes (codon MP), slow flowing rivers (codon Tc), lotic habitats (codon $\mathrm{Tb}$ ).

The morphological classification of Kruk et al. (2010) is given in Appendix 1. This classification is made on 8 groups characterized by differing morphological traits, such as presence of flagella, presence of siliceous features, presence of mucilage. These morphological groups are well correlated with functional properties such as growth rate, sinking rate.
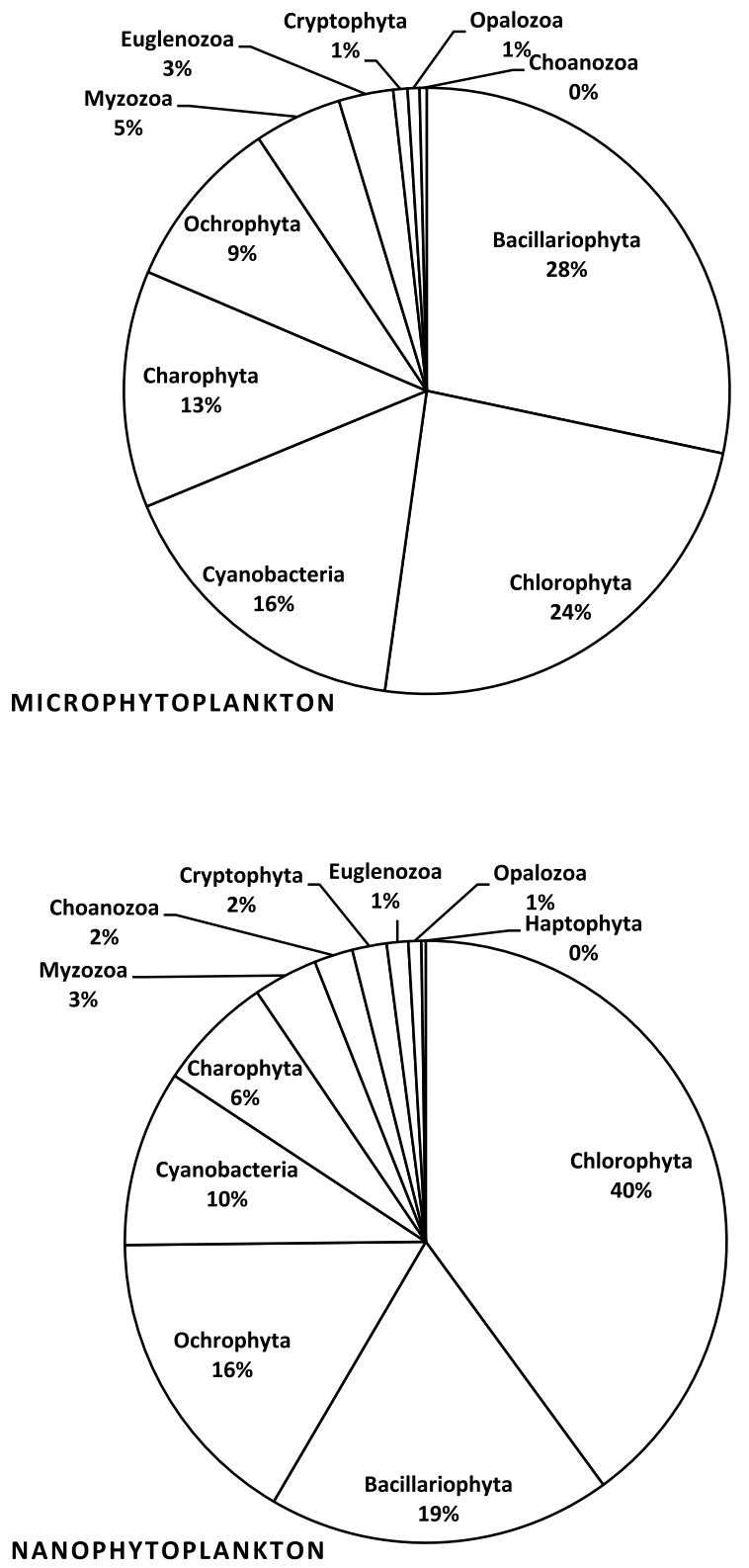

Fig. 2. Number taxa in microphytoplankton and nanophytoplankton per Phyla present in the phytoplankton trait database (Appendix 1).

For each taxon given in Appendix 1, its belonging to nanophytoplankton and microphytoplankton is also given. Nanophytoplanktonic taxa correspond to algae with a cell (or colony) whose maximal length is less than $20 \mu \mathrm{m}$ and their biovolume is less than $10000 \mathrm{\mu m}^{3}$; microphytoplanktonic taxa have a maximal length greater than $20 \mu \mathrm{m}$ and/or a biovolume greater than $10000 \mathrm{\mu m}^{3}$. The attribution of taxa to nano or microphytoplankton is based on the values of the "reference biovolume" and the "maximal length of the algal object" given in Appendix 1. Nanophytoplanktonic taxa have a high surface/ volume ratio which facilitate nutrient uptake, given their small size they quickly reproduce and have a low sinking rate. On the other hand, nanophytoplankton species are easily grazed by zooplankton: they are more edible. Microphytoplanktonic taxa have a low sinking rate, a smaller surface/volume ratio and 


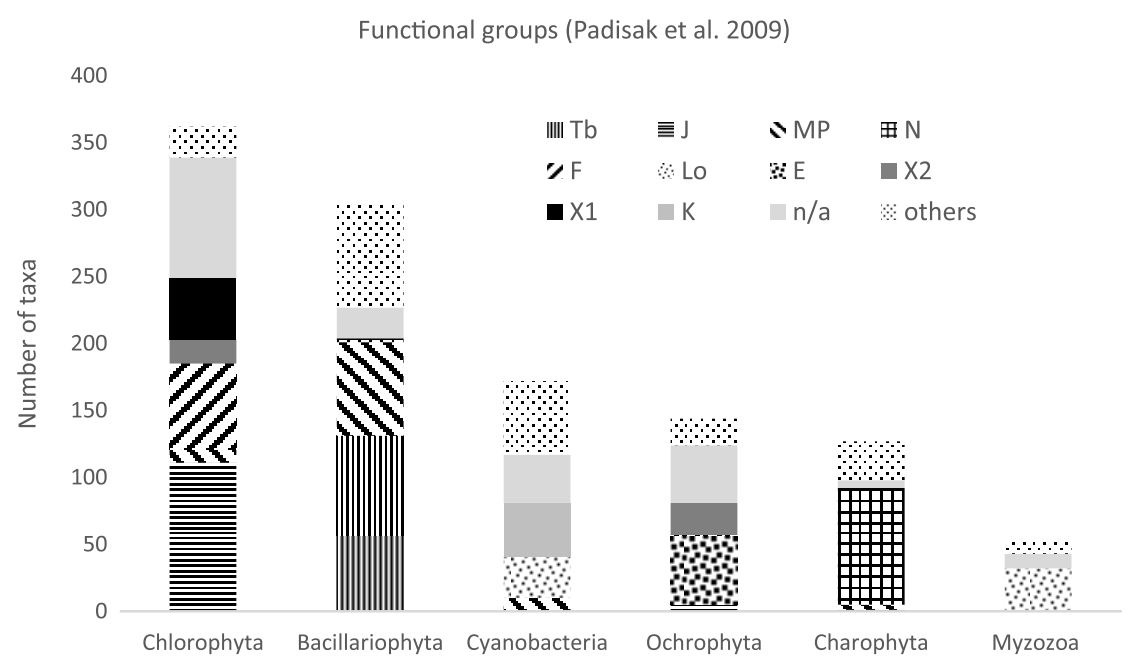

Morphological groups (Kruk et al. 2010)

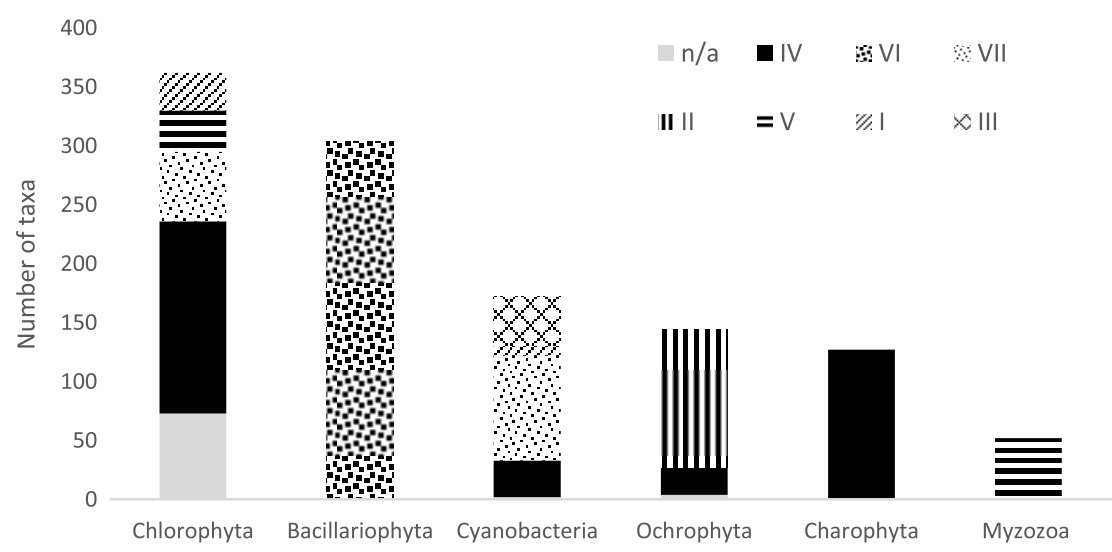

Fig. 3. Number of taxa per Phyla (a) in the functional (Padisak et al., 2009) and (b) in the morphological (Kruk et al., 2010) groups. "n/a": nonattributed taxa to functional and morphological groups, "others": only the most frequent codons are represented, the other are gathered in "others".

therefore a smaller nutrient uptake capacity. On the other hand, they are more resistant to zooplankton grazing: they are less edible (e.g. Mostajir et al., 2001; Domaizon et al., 2003; Tada et al., 2003).

Finally, Appendix 1 gives a physiological trait, the organic carbon ratio (Wetzel and Likens, 2000) for each taxon. This ratio is an estimation of organic carbon content of algae, it correspond to the general ratio of cellular carbon to cell volume. In Appendix 1, it is given for each algal class and enable to estimate the organic carbon content of algae $(\mu \mathrm{gC})$ based on algal biovolume (in $\mu \mathrm{m}^{3}$ ). The phytoplankton biovolume is considered to have a density equivalent to water (so $10^{6} \mu \mathrm{m}^{3} / \mathrm{L}=1 \mu \mathrm{g} / \mathrm{L}$ ), so phytoplankton carbon $(\mu \mathrm{g} \mathrm{C} / \mathrm{L}$ ) is the phytoplankton biomass $(\mu \mathrm{g} / \mathrm{L})$ multiplied by the organic carbon ratio.

\subsection{Taxonomy}

Taxonomy of each taxon is given from Empire to infraspecific level according to Algaebase (Guiry and Guiry, 2014) in Appendix 1. The memberships of taxa to the different traits cell and colony, functional and morphological groups were explored with simple descriptive statistics.

\section{Results and discussion}

A total of 1224 taxa is codified in Appendix 1. These taxa were encountered mostly during surveys carried out in the framework of the long term monitoring of the large sub-alpine lakes in France Lake Geneva (e.g. Rimet et al., 2016), Lake Aiguebelette, Lake Annecy (e.g. Jacquet et al., 2014), Lake Bourget (e.g. Kerimoglu et al., 2017; Rivera et al., 2017) but also low-land lakes like lac du Der (North East France, Rolland et al., 2009) and other remote lakes (e.g. Martinet et al., 2014). A majority of them belongs to Chlorophyta (30\%), Bacillariophyta (25\%), Cyanobacteria (14\%) and Charophyta (i.e. Zygnemataceae, 10\%).

A majority of the taxa are belonging to the microphytoplankton $(65 \%)$. Microphytoplankton is mostly composed by Bacillariophyta (most taxa rich genera are Cymbella, Fragilaria, Navicula Bory, Nitzschia Hassall) and Chlorophyta (e.g. Coelastrum Nägeli, Monoraphidium 
Komárková-Legnerová, Scenedesmus, Ulothrix Kützing) taxa. On the other hand, nanophytoplankton is mostly composed by unicellular Chlorophyta taxa (e.g. Chlamydomonas Ehrenberg, Scenedesmus) and unicellular diatoms (e.g. Cyclotella (Kützing) Brébisson, Stephanodiscus Ehrenberg, small Navicula, Puncticulata H. Håkansson) (Fig. 2).

Repartition of the different functional groups of Padisak et al. (2009) and Kruk et al. (2010) in the algal Phyla show a none phylogenic distribution since taxa of a given phylum belong to different functional groups (Fig. 3). When focusing on functional groups of Padisak et al. (2009), most of Chlorophyta taxa belong to codon J (shallow, mixed, highly enriched systems) and codon F (clear, deeply mixed mesoeutrophic lakes). Diatom taxa belong mostly to codon $\mathrm{Tb}$ (highly lotic environments) and Mp (frequently stirred up, inorganically turbid shallow lakes). Indeed, a high proportion of diatom taxa of the database are mostly of benthic habitats and not specifically planktonic. Finally, Cyanobacteria taxa belong to codon $\mathrm{K}$ (shallow, nutrient-rich water columns) and Lo (summer epilimnia in mesotrophic lakes).

When focusing on functional groups of Kruk et al. (2010), most of Chlorophyta taxa belong to group IV (medium sized organisms lacking specialized traits as Monoraphidium, Coelastrum, Scenedesmus etc...) and VII (large mucilaginous colonies as Oocystis Nägeli, Coenochloris Korshikov etc ...). Diatoms all belong to group VI (non-flagellated organisms with siliceous exoskeletons). Cyanobacteria taxa mostly belong to group VII (large mucilaginous colonies as Aphanothece Nägeli, Aphanocapsa Nägeli ...).

Nowadays, this database is routinely used in monitoring reports and scientific studies to assess eutrophication of lakes (e.g. with the total biomass or with the Brettum index, see Jacquet et al., 2014, Rimet, 2017), links with zooplankton and fish communities (e.g. with edible functional groups of nano/microphytoplankton classes see Rimet, 2017; Kerimoglu et al., 2017) or global warming (e.g. Berthon et al., 2014).

\section{Perspectives}

Such database is encompassing 1224 taxa, but for sure, it is far from being complete compared to the enormous diversity of microalgae. Indeed, diatoms encompass more than 100000 extent species (Mann and Vanormelingen, 2013), Chlorophyceae more than 6500 described taxa and Cyanobacteria more than 4600 described taxa (Guiry and Guiry, 2014). This database surely encompasses the most frequently observed taxa in temperate lakes. But it would be definitely necessary to have a much more collaborative work around such topic in order to have similar trait database than the extensive trait databases existing for higher plants like the TRY database where more than a hundred of scientists collaborated together (e.g. Kattge et al., 2011).

\section{Supplementary Material}

Appendix 1.

The Supplementary Material is available at https://www. limnology-journal.org/10.1051/limn/2018009/olm.
Acknowledgments. We thank Orlane Anneville for pushing me to publish this database.

\section{References}

Afnor. 2006. EN 15204 - Water quality - Guidance standard on the enumeration of phytoplankton using inverted microscopy (Utermöhl technique). Afnor: 1-39.

Anneville O, Ginot V, Angeli N. 2002. Restoration of Lake Geneva: expected versus observed responses of phytoplankton to decreases in phosphorus. Lakes Reserv Res Manag 7: 67-80.

Anneville O, Dur G, Rimet F, Souissi S. 2017. Plasticity in phytoplankton annual periodicity: an adaptation to long-term environmental changes. Hydrobiologia. DOI:10.1007/s10750-0173412-z.

Berthon V, Alric B, Rimet F, Perga ME. 2014. Sensitivity and responses of diatoms to climate warming in lakes heavily influenced by humans. Frehwater Biol 59: 1755-1767. doi:10.1111/fwb. 12380 .

Bourrelly P. 1981. Les Algues d'eau douce, Tome II: les algues jaunes et brunes. Paris, France: Edition Boubée \& Cie, 517 p.

Brettum P. 1989. Algen als Indikatoren für die Gewasserqualitat in norwegischen Binnenseen. Norsk Institutt for vannforskning NIVA. Report, $102 \mathrm{p}$.

Cantonati M, Lowe RL. 2014. Lake benthic algae: toward an understanding of their ecology. Freshw Sci 33: 475-486.

Copeland C. 2016. Clean water act: a summary of the law. Congressional Research Service, report, $10 \mathrm{p}$.

Dokulil M, Teubner K, Greisberger S. 2005. Typenspezifische Referenzbedingungen für die integrierende Bewertung des ökologischen Zustandes stehender Gewasser Österreichs gemss der EU-Wasserrahmenrichtlinie. Modul 1: Die Bewertung der Phytoplankton struktur nach dem Brettum-Index. Projektstudie Phase 3, Abschlussbericht. Im Auftrag des Bundesministeriums für Land- und Forstwirtschaft, Umwelt und Wasserwirtschaft, Wien, $50 \mathrm{p}$.

Domaizon I, Viboud D, Fontvieille D. 2003. Taxon-specific and seasonal variations in flagellates grazing on heterotrophic bacteria in the oligotrophic Lake Annecy - importance of mixotrophy. FEMS Microbiol Ecol 1591: 1-13.

Druart JC, Leboulanger C, Rolland A. 2004. Evolution du phytoplancton du Léman. Campagne 2003. CIPEL. Rapport, pp. 69-79.

European Commission. 2000. Directive 2000/60/EC of the European parliament and of the council of 23rd October 2000 establishing a framework for Community action in the field of water policy. Off $J$ Eur Communities 327: 1-72.

European Standardisation Committee. 2014. EN 16695 - Water quality - Guidance on the estimation of microalgal biovolume. CEN Stand: $1-238$

Feret L, Bouchez A, Rimet F. 2017. Benthic diatom communities in high altitude lakes: a large scale study in the French Alps. Int $J$ Limnol 53: 411-423.

Guiry MD, Guiry GM. 2014. AlgaeBase. World-wide electronic publication. Galway: National University of Ireland. http://www. algaebase.org; searched on 24 november 2014.

Jacquet S, Domaizon I, Anneville O. 2014. The need for ecological monitoring of freshwaters in a changing world: a case study of Lakes Annecy, Bourget, and Geneva. Environ Monit Assess 186: 3455-3476. doi: 10.1007/s10661-014-3630-z.

Jacquet S, Arthaud F, Barbet D, et al. 2017. Suivi environnemental des eaux du lac du Bourget pour l'année 2016. Rapport INRACISALB-CALB, $211 \mathrm{p}$. 
Jones RI. 2000. Mixotrophy in planktonic protists: an overview. Freshw Biol 45: 219-226. doi:10.1046/ j.1365-2427.2000.00672.x.

Kattge J, Diaz S, Lavorel S, et al. 2011. TRY - a global database of plant traits. Glob Chang Biol 17: 2905-2935. doi:10.1111/ j.1365-2486.2011.02451.x.

Kerimoglu O, Jacquet S, Vinçon-Leite B, Lemaire B, Rimet F, Soulignac F, Trevisan D, Anneville O. 2017. Modelling the plankton groups of the deep, peri-alpine Lake Bourget. Ecol Model 359: 415-433.

Kruk C, Huszar V, Peeters E, et al. 2010. A morphological classification capturing functional variation in phytoplankton. Freshw Biol 55: 614-627.

Lang C. 1975. Etude du phytoplancton des eaux Vaudoises. CIPEL, report, pp. 69-89.

Makarewicz JC, Bertram P, Lewis TW. 1998. Changes in phytoplankton size-class abundance and species composition coinciding with changes in water chemistry and zooplankton community structure of Lake Michigan, 1983 to 1992. J Gt Lakes Res 24: 637-657.

Mann DG, Vanormelingen P. 2013. An inordinate fondness? The number, distributions and origins of diatom species. $J$ Eukaryot Microbiol 60: 1-26.

Martinet J, Descloux S, Guédant P, Rimet F. 2014. Phytoplankton functional groups for ecological assessment in young sub-tropical reservoirs: case study of the Nam-Theun 2 Reservoir, Laos, SouthEast Asia. J Limnol 73: 536-550.

Mostajir B, Gosselin M, Gratton Y, et al. 2001. Surface water distribution of pico- and nanophytoplankton in relation to two distinctive water masses in the North Water, Baffin Bay, during fall. Aquat Microb Ecol 23: 205-212.

Nygaard G. 1949. Hydrobiological studies on some Danish ponds and lakes. Part II: the quotient hypothesis and some little knwon plankton organisms. Vidensk Danske Selsk Biologica Skripta 7: 1-293.

Padisak J, Crossetti LO, Naselli-Flores L. 2009. Use and misuse in the application of the phytoplankton functional classification: a critical review with updates. Hydrobiologia 621: 1-19.

Pelletier JP, Druart JC, Revaclier R. 1997. Evolution du phytoplancton du Léman. Campagne 1996. CIPEL, report, pp. 69-77.

Pinay G, Gascuel C, Ménesguen A, Souchon Y. 2017. Eutrophisation: manifestation, causes, conséquences et prédictibilité. Ifremer: CNRS, INRA, 145 p.

Revaclier R, Balvay G, Druart JC, Pelletier J. 1988. Evolution du plancton du Léman. Campagne 1987. Rapports sur les études et recherches entreprises dans le bassin lémanique. CIPEL, pp. $55-75$.
Reynolds CS, Huszar V, Kruk C, Naselli-Flores L, Melo S. 2002. Toward a functional classification of the freshwater phytoplancton. J Plankton Res 24: 417-428.

Rimet F. 2017. The phytoplankton of Lake Geneva. Campagne 2016. CIPEL, pp. 81-92.

Rimet F, Druart JC. 2009. Phytoplancton du Léman. Campagne 2008. CIPEL, pp. 91-102.

Rimet F, Druart JC, Anneville O. 2009. Exploring the dynamics of plankton diatom communities in Lake Geneva using emergent selforganizing maps (1974-2007). Ecol Inform 4: 99-110.

Rimet F, Bouchez A, Tapolczai K. 2016. Spatial heterogeneity of littoral benthic diatoms in a large lake: monitoring implications. Hydrobiologia 771: 179-193.

Rivera S, Vasselon V, Jacquet S, Ariztegui D, Bouchez A, Rimet F. 2017. Metabarcoding of lake benthic diatoms: from structure assemblages to ecological assessment. Hydrobiologia 807: 37-51. doi:10.1007/s10750-017-3381-2.

Rolland A, Bertrand F, Maumy M, Jacquet S. 2009. Assessing phytoplankton structure and spatio-temporal dynamics in a freshwater ecosystem using a powerful multiway statistical analysis. Wat Res 43: 3155-3168.

Salmaso N, Padisak J. 2007. Morpho-functional groups and phytoplankton development in two deep lakes (Lake Garda, Italy and Lake Stechlin, Germany). Hydrobiologia 578: 97-112.

Stickney HL, Hood RR, Stoecker DK. 2000. The impact of mixotrophy on planktonic marine ecosystems. Ecol Model 125: 203-230. doi:10.1016/S0304-3800(99)00181-7.

Tada K, Sakai K, Nakano Y, Takemura A, Montani S. 2003. Sizefractioned phytoplankton biomass in coral reef waters off Sesoko Island, Okinawa, Japan. J Plankt Res 25: 991-997.

Tapolczai K, Bouchez A, Stenger-Kovacs C, Padisak J, Rimet F. 2016. Trait-based ecological classifications for benthic algae: review and perspectives. Hydrobiologia 776: 1-17.

Thackeray SJ, Noges P, Dunbar MJ, et al. 2013. Quantifying uncertainties in biologically-based water quality assessment: a panEuropean analysis of lake phytoplankton community metrics. Ecol Indic 29: 34-47.

Thunmark S. 1945. Zur soziologie des susswasserplanktons. Eine methodish-okologishe studie. Folia Limnol Scand 3: 1-66.

Tittel J, Wiehle I, Wannicke N, et al. 2009. Utilisation of terrestrial carbon by osmotrophic algae. Aquat Sci 71: 46-54. doi:10.1007/ s00027-008-8121-2.

Utermöhl H. 1958. Zür Vervollkommung der quantitative Phytoplankton Methodik. Mitt Internat Ver Theor Anqew Limnol 9: 1-38.

Violle C, Navas ML, Vile D, et al. 2007. Let the concept of trait be functional. Oikos 116: 882-892.

Wetzel RG, Likens G., 2000. Limnological analyses. New York, USA: Springer-Verlag, $429 \mathrm{p}$.

Cite this article as: Rimet F, Druart J-C. 2018. A trait database for Phytoplankton of temperate lakes. Ann. Limnol. - Int. J. Lim. 54: 18 